\title{
Problem-based learning with role-playing: An experiment on prospective mathematics teachers
}

\author{
Ita Chairun Nissa ${ }^{1}$, I Ketut Sukarma ${ }^{1}$, Sutarto ${ }^{1}$
}

\begin{abstract}
Abstrak: Penelitian ini bertujuan untuk menguji pengaruh pembelajaran berbasis masalah dengan bermain peran terhadap pemecahan masalah calon guru matematika yang mengambil mata kuliah aljabar linier pada semester ketiga. Penelitian ini adalah eksperimen semu dengan desain post-test kelompok kontrol yang tidak setara. Empat puluh dua calon guru matematika terlibat dalam penelitian ini dan mereka dibagi menjadi kelompok eksperimen (diajarkan menggunakan pembelajaran berbasis masalah dengan bermain peran) dan kelompok kontrol (diajarkan menggunakan pembelajaran berbasis masalah saja). Data dikumpulkan menggunakan tes dan rekaman video. Tes menghasilkan data tentang kemampuan calon guru untuk memecahkan masalah aljabar linier dan rekaman video yang menghasilkan transkrip diskusi calon guru ketika mereka memainkan suatu peran. Data dianalisis melalui dua tahap. Pertama, hasil tes dianalisis secara kuantitatif menggunakan uji-F untuk mengukur varian kedua kelompok, kemudian mengukur normalitas data menggunakan interpretasi skewness dan kurtosis, dan akhirnya dilakukan uji-t satu pihak untuk mengukur perbedaan hasil tes antara kedua kelompok. Kedua, sampel hasil tes calon guru matematika dari kedua kelompok dan transkrip diskusi dianalisis secara kualitatif untuk memperkuat temuan kuantitatif dan mengungkapkan bagaimana pembelajaran berbasis masalah dengan bermain peran dapat mendukung pemecahan masalah pada calon guru matematika yang menempuh pendidikan guru. Penelitian ini menunjukkan bahwa pembelajaran berbasis masalah dengan bermain peran lebih efektif untuk meningkatkan keterampilan pemecahan masalah calon guru matematika daripada hanya melakukan pembelajaran berbasis masalah saja. Bermain peran memberikan kesempatan kepada mahasiswa untuk dapat berpikir dan mengomunikasikan matematika secara formal dalam konteks pemecahan masalah.
\end{abstract}

Kata kunci: Pembelajaran berbasis masalah, Bermain peran, Calon guru matematika, Pemecahan masalah

Abstract: This study aimed to examine the effect of problem-based learning $(\mathrm{PbL})$ with role-playing toward problem-solving skills of prospective mathematics teachers' (PMTs) who take linear algebra courses. The study was a quasi-experimental with a non-equivalent control group post-test only design. Forty-two PMTs were involved and divided into experimental (taught using PbL combined with role-playing) and control groups (taught using $\mathrm{PbL}$ only). Data were collected using tests and video recordings. The test produces data on PMTs' problem-solving skills on linear algebra problems and video recordings resulted in the transcripts of PMTs' discussion when they played a role. Data were analyzed through two stages. Firstly, the results of the test were analyzed quantitatively using F-test to measure the variance of the two groups, then measure the normality of the data using the interpretation of skewness and kurtosis, and finally, one-tail t-test to measure differences in test results between the two groups. Secondly, the sample of PMTs' works in two groups and the transcripts of their conversation were qualitatively analyzed to strengthen the quantitative finding and reveal how PbL with role-playing support PMTs' problem-solving in teacher education. This study shows that $\mathrm{PbL}$ with role-playing is more effective to improve students' problem-solving skills

\footnotetext{
${ }^{1}$ Department of Mathematics Education, Universitas Pendidikan Mandalika, Jln Pemuda No. 59A, Mataram 83125, Indonesia, itachairunnissa@ikipmataram.ac.id
} 
than solely doing problem-based learning. Doing a role-playing provided students with the opportunity to be able to think and speak mathematics more formally in the context of problemsolving.

Keywords: Problem-based learning, Role-playing, Prospective mathematics teachers, Problemsolving

\section{A. Introduction}

Prospective mathematics teachers who are taking a course in the teacher education program have to face two main challenges: (1) learning mathematics as mathematicians, formal thinking that is related to facts, procedures, and concepts of mathematics, and also doing mathematics that involve exploration, logical reasoning, look for patterns, and problem-solving (Brandt, Lunt, \& Meilstrup, 2016), and (2) forming themselves into mature individuals as prospective teachers, a continuous and lifelong learning process that requires the skills of self-reflection, communication, and cooperation (Viholainen, Asikainen, \& Hirvonen, 2014). On the other hand, there is an issue where the teacher education program rarely gives their students problems that produce meaningful and substantial contributions since bringing up the right topics and problems is the main source of the difficulty (Alayont et al., 2014). This challenge cannot be faced if the learning approach in teacher education is dominated by the activities of explaining theoretical knowledge oriented to textbooks and lecture notes. Such an approach tends to make students passive learners and lack the skills needed in the future (Polly et al., 2013), whereas the outcomes of students' learning expected to be achieved are creativity, problem-solving skills, decisionmaking skills, communication skills, leadership, and team-building (Biggs \& Tang, 2011).

Many educational innovations are implemented to support the outcomes of students' learning and one of the innovations is problem-based learning (Dochy et al., 2003). Problembased learning $(\mathrm{PbL})$ refers to the constructivist principles of teaching and learning to achieve important content knowledge and problem-solving (Murray-Harvey et al., 2005). It was originally designed to help medical students in solving clinical problems. After its successful implementation in various fields of medical education, then $\mathrm{PbL}$ implemented in other fields of higher education (Hung, Jonassen, \& Liu, 2008), including teacher education. Some characteristics of $\mathrm{PbL}$ that implemented in the teacher education are: (1) focusing on the problem: prospective teachers build knowledge stimulated by problems and applied back to problems; (2) student-centered: faculty cannot dictate learning to prospective teachers because they must be directed as independent learners; (3) self-reflective: prospective teachers can reflect on the extent of their understanding and adjust to appropriate learning strategies; and finally (4) lecturers are facilitators who support and model the problem-solving process, facilitate groups, and investigate student knowledge (Dolmans et al., 2005; Hung, Jonassen, \& Liu, 2008; HmeloSilver, 2004)

As PbL has been widely used in higher education (Ar \& Katranc1, 2014; Dolmans et al., 2005), it is apparently true that $\mathrm{PbL}$ is an effective method for prospective teacher programs in higher education (Murray-Harvey et al., 2005). Higher education uses PbL to engage prospective teachers actively in learning since this approach has a positive influence on their learning (Davidson et al., 2014). PbL has a good impact on the problem-solving skills of prospective teachers. The PbL participants learned significantly better in constructing the main problem, elaborating on the problem, connecting solutions with the problem, and using various resources 
(De Simone, 2008). Prospective teachers learn better by finding solutions to open problems, struggling with complex activities, and discussing problems with classmates. This activity leads better than passive listening to lectures (Argaw et al., 2017). In general, $\mathrm{PbL}$ has a robust positive effect on students' knowledge and skills (Dochy et al., 2003).

$\mathrm{PbL}$ facilitates PMTs to acquire skills in problem-solving, communication, and interpersonal skills, however, these skills should constantly be taught up to become pre-service teachers or professional teachers (Armstrong, 2003). Currently, role-playing was used in some teacher training education programs to develop the professional skills of mathematics teachers (Armstrong, 2003). Some pre-service teacher training programs used role-playing to improve the skills to provide insight into students' perceptions and their learning styles, and discuss challenges in real teaching practice and how problems were overcome (Gregory \& Masters, 2012). Playing various roles influenced PMTs thinking during the learning process. Role-playing provides an opportunity for them to learn how mathematics can be taught (Kilgour et al., 2015). Role-playing was used to provide a model for prospective teachers in higher education about how to think and work like a mathematician (Howes \& Cruz, 2009). Role-playing has succeeded in improving a deeper understanding of concepts and developing communication and collaborative skills (Jackson \& Walters, 2000).

To facilitate PMTs in order to have sufficient skills as mathematics teachers in the future, we need a learning approach that could engage PMTs in challenging activities that provide motivation and collaboration. $\mathrm{PbL}$ can be combined with role-playing, and this collaboration will create a rich learning environment for students to be able to communicate their knowledge, work in teams, and make decisions based on facts and cases (Bhattacharjee \& Ghosh, 2013). $\mathrm{PbL}$ with role-playing has the potential to become innovative learning that makes the classroom more dynamic with verbal and non-verbal activities, and also improving the cognitive processes of problem-solving (Chan, 2012). In the Indonesian context, as far as our concern, we found some related studies involving $\mathrm{PbL}$ combined with role-playing for prospective teachers. Prastiti et al. (2014) implemented PbL with role-playing on the elementary prospective teachers. They learned about classroom action research through microteaching practice by playing the roles of teacher, students, and observer. This study showed that prospective teachers became more active and able to understand the concept of classroom action research much better. Syaifudin and Sulistyaningrum (2015) investigate the impact of $\mathrm{PbL}$ with role-playing on the language and literary prospective teachers. $\mathrm{PbL}$ with role-playing was used to build an understanding of the concepts and apply them in daily life both independently and in groups. This study showed that the prospective teachers perceive excited in learning and more active in their classroom activities.

Based on the aforementioned studies, role-playing tends to emphasize the activity of playing the role of a person's character such as teacher, school student, observer, and others. However, the concept of role-playing in mathematics education is different from other fields. Playing a role in mathematics education is a pedagogical approach that aims to improve understanding of content and interaction among group members. It does not mean playing the real character but rather playing a role to interact or dialogue about mathematics (Zazkis \& Sinclair, 2013). Therefore, role-playing in this study was conducted not in the form of portraying a person's character or behavior, such as a teacher, school students, or another public figure. It refers to playing a role that enables the emergence of PMTs' participation to improve their understanding of a mathematics topic and able to implement this understanding in problem-solving. 
The important part of role-playing in PbL is setting the PMTs roles. Setting the role of PMTs' groups to be active together can create an open learning environment where all students have the same opportunity to perform their ideas (Fata, Kasim, \& Juniyana, 2016). Therefore, we have made some rules for the experimental group namely (1) divides PMT into three groups, each of which will play the role of presenter, checker, and observer, (2) the presenter and checker groups are in small groups, each consisting of five students, while the other students become observer groups, (3) the presenter group has roles to present some topics through inductivedeductive or deductive-inductive paradigm, showing proof, and explaining a case, (4) the checker group has roles to analyze the explanation of the presenter group, finding problems or cases that cannot be justified by the presenter group, and asking critical questions for testing and exploring the material, and (5) the observer group has roles to observe the discussion process, assess the mathematical conversation between the two groups, provide feedback, and alternative problem-solving for cases that are unable to be resolved by the presenter group and the checker group.

The PMTs played these roles through discussion activities. The main purpose of using discussion is to promote students to evaluate some topics or solutions, to clarify the fundamental for their judgments; and to become conscious of other points of view (Rahman et al., 2011). Role-playing helps PMTs to understand the perspective of how one should learn mathematics and use it to solve problems (Kilgour et al., 2015). Giving students an opportunity to present (which is the role of presenter group), clarify (which is the role of checker group), and elaborate (which is the role of observer group) on their own or other students' utterance is a helpful way to keep a discussion moving along and on target (Rahman et al., 2011). Designing structure roles is the key to determining how successfully the discussion will promote learning for the participants (Goodyear, 2005). Structured discussions create $\mathrm{PbL}$ going properly within the time available, encourage participants to engage effectively with the topics being studied, and dissolve into multi-way conversations involve the whole group (Wertsch, 2002).

In this circumstance, we argue that $\mathrm{PbL}$ with role-playing seems promising to support PMTs in dealing with problem-solving at mathematics topics such as linear algebra. Linear algebra is the main mathematical subjects taught in higher education. However, this teaching has always been difficult. In some countries, in the last two decades, it became an active area field for research in mathematics education (Dorier, 2003). The main difficulties in learning linear algebra have to do with the variety of mathematics' expressions, representation, construction and objects settings (Jupri \& Drijvers, 2016). Based on these problems, PbL with role-playing could promote collaborative thinking and exploratory discussion in mathematics classroom. Enhancing group activity in which the focus tends on providing an agreed explanation and justification for a particular strategy and solution rather than finding the right answer. Therefore, the responsibility for determining correct or acceptable answers shifts from teachers and textbooks to the classroom members as a community of learners. However, the most important is the potential benefits for individual learners that can increase from participating in effective group work, not only in terms of gaining insights from the contributions of others but also through having an opportunity to externalize and make explicit their own thinking to their partners and, crucially, to themselves. In addition to the promising features of $\mathrm{PbL}$ with roleplaying, the related studies in mathematics teacher education in the Indonesian context should be initiated. This study are expected to make positive contributions as alternative learning in higher education that improves the skills of a prospective mathematics teacher in solving linear algebra problems. The present study aimed to address the following two main problems: 
1. Is $\mathrm{PbL}$ with role-playing more effective than $\mathrm{PbL}$ toward PMTs' problem-solving in linear algebra?

2. To what extent $\mathrm{PbL}$ with role-playing rather than $\mathrm{PbL}$ to support PMTs' problem-solving in linear algebra?

\section{B. Methods}

This part explains (1) research design, (2) participants and sampling techniques, and (3) procedures, data collection, and analysis.

\section{Research Design}

A quasi-experimental with non-equivalent control group post-test only design was designed for the present study as follows (Miliyawati \& Herman, 2019):

\begin{tabular}{ll}
$G_{1}$ & $X_{1} T$ \\
\hline$G_{2}$ & $X_{2} T$
\end{tabular}

$\mathrm{G}_{1}=$ experimental group, $\mathrm{G}_{2}=$ control group, $\mathrm{X}_{1}=\mathrm{PbL}$ with role-playing, $\mathrm{X}_{2}=\mathrm{PbL}$, and $\mathrm{T}=$ mathematical testing on the both groups.

The differences in treatments between the experimental and control group are shown in Table 1. We embedded the role-playing process involves three steps: preparation, presentation, and analysis (Bender, 2005) into five phases of PbL adapted from Nurtanto and Sofyan (2015).

Table 1. Treatments on the experimental and control group

\begin{tabular}{|c|c|c|}
\hline $\begin{array}{c}\text { Problem-Based Learning } \\
\text { (PbL) Phase }\end{array}$ & $\begin{array}{c}\text { Experimental Group (PbL } \\
\text { with Role-Playing) }\end{array}$ & $\begin{array}{c}\text { Control-Group (PbL } \\
\text { only) }\end{array}$ \\
\hline $\begin{array}{l}\text { Phase } 1 \text { - Student orientation } \\
\text { on the problem }\end{array}$ & $\begin{array}{l}\text { The lecturer and students } \\
\text { formulate the goal of the } \\
\text { mathematical problem-solving } \\
\text { activities that will gain together. }\end{array}$ & $\begin{array}{l}\text { The lecturer explains the } \\
\text { purpose of the } \\
\text { mathematical problem- } \\
\text { solving activities that will } \\
\text { be taught. }\end{array}$ \\
\hline Phase 2 - Organizing students & $\begin{array}{l}\text { Students are organized into } \\
\text { groups and divided according to } \\
\text { their respective roles. }\end{array}$ & $\begin{array}{l}\text { Students solve problems } \\
\text { individually. }\end{array}$ \\
\hline $\begin{array}{l}\text { Phase } 3 \text { - Guiding } \\
\text { individual/group investigations }\end{array}$ & $\begin{array}{l}\text { Investigation in groups through } \\
\text { the roles of "presenter", } \\
\text { "checker", and "observer". }\end{array}$ & Individual investigation \\
\hline $\begin{array}{l}\text { Phase } 4 \text { - Develop and present } \\
\text { students' works }\end{array}$ & $\begin{array}{l}\text { Showing the performance of } \\
\text { problem-solving as a group }\end{array}$ & $\begin{array}{l}\text { Showing the performance } \\
\text { of problem-solving as an } \\
\text { individual }\end{array}$ \\
\hline $\begin{array}{l}\text { Phase } 5 \text { - Analyze and evaluate } \\
\text { the process of problem-solving }\end{array}$ & $\begin{array}{l}\text { The groups collaborate to } \\
\text { reflect the problem-solving } \\
\text { process }\end{array}$ & $\begin{array}{l}\text { Reflection of problem- } \\
\text { solving was performed } \\
\text { individually }\end{array}$ \\
\hline
\end{tabular}

\section{Participants and Sampling Technique}

In this study, two groups of PMTs take a linear algebra course. Each group has 21 PMTs, so the total of respondents involved in this study is 42 . We have examined the variance of the two groups using the F-test and the results show that the two groups were not homogeneous. In this case, we used a purposive sampling technique to determine the experimental and control 
group. In the first four meetings, we conducted lectures using the same method for both groups. The method referred to the discussion method. We use this method to collect information on which groups of PMTs are actively engaged in responding to questions from their partners and lecturer. Since PMTs in the experimental group were treated through PBL with role-playing, then we choose the PMTs group that is more active in talk mathematically as the experimental group. Kotsopoulos (2010) highlighted the importance of students' willingness and ability to speak can influence communicative interactions in groups. On the other hand, PMTs from the control group tend to solve mathematics problems individually or sometimes in a group but less of interactive communication. Since the difference of variance from both groups, then it will be a limitation of our study.

\section{The procedure, Data Collection, and Analysis}

Data were collected using test and video recording. The test was validated by the experts and the result was valid as the instrument in this study. The test was assessed by giving a score from 1 to 5 which shows the ability of the test to measure problem-solving skills of PMTs on linear algebra. Then, the score given by the expert is then matched with the criteria from Wulanzani et al. (2016) and the results show that the instrument was valid with minor revision related to various variables and equations in a linear system. The next stage of the testing of the instrument is to conduct a reliability test. The reliability test in this study performed with a product-moment correlation. When the value of the $r$-statistic is larger than the value of the $r$ distribution table at $\alpha=0.05$, then the test is reliable. The test was used to collect data about PMTs' problem-solving skills. This data indicated by a description of the answers given by PMTs which were then analyzed and expressed in the form of scores and grades. Video recording was used to collect conversation data when PMTs played a role in class discussions. The test was given as a question for the final semester exam. The time of the test was scheduled by the faculty. The test runs for 90 minutes under the supervision of two lecturers. On the other hand, PMTs' mathematical conversations in group discussions were recorded during the lecture process in one semester. The recording was not performed every class meeting, only when PMTs are asked to elaborate a concept, identify some important properties, or analyze a theorem. In the case when they did some exercises to solve linear algebra problems from the textbook, a recording is not performed. However, the work of PMTs remains documented for description in this study. Thus, the recording was performed only to document PMTs' conversations mathematically when they are playing roles.

The PMTs' test score was statistically analyzed which consisted of the validity test, reliability test, homogeneity test, normality test, and hypothesis test. All quantitative data analysis was performed using the data analysis tools on Microsoft Excel version 2010. Before testing the hypothesis, we performed the homogeneity and normality of the PMTs' test scores. The standard F-test was used to test the homogeneity of variance. When the value of $F$-statistic is larger than the value of $F$-distribution table at $\alpha=0.05$, then variances are homogeneous. Furthermore, Skewness and Kurtosis were used to test the normality of data. The data has a normal distribution if it meets two conditions, i.e. (1) approximately symmetric: the mean is approximately equal to the median(-1.96<Z-Skewness<+1.96)and (2) mesokurtic: distribution that is moderate in breadth and curves with medium peaked height $(-1.96<Z$-Kurtosis $<+1.96)$. Following these, we performed hypothesis testing using a one-tail t-test. The null hypothesis proposed in this study was $H_{o}: \mu_{1}=\mu_{2}$ (the average of math test scores from PMT's taught with $\mathrm{PbL}$ with role-playing is higher than the average of math test scores from PMT's taught with 
$\mathrm{PbL}$ only), while the alternative hypothesis was $H_{a}: \mu_{1}>\mu_{2}$ (the average of math test scores from PMT's taught with $\mathrm{PbL}$ with role-playing is larger than the average of math test scores from PMT's taught with $\mathrm{PbL}$ only). When the value of $t$-statistics is larger than the value of $t$ distribution table then $H_{o}$ is rejected at $\alpha=0.05$. For this hypothesis testing, we can decide that there is a significant difference in problem-solving skills between PMTs taught by PbL with role-playing and PMTs taught by $\mathrm{PbL}$ only, which means that $\mathrm{PbL}$ with role-playing is effective to improve the PMTs' problem-solving skills.

Furthermore, quantitative data that has been produced through hypothesis testing must then be supported by qualitative data sourced from video data and the work of PMTs. Data in the video was converted into an audio transcript to get direct exposure to the conversation in addition to seeing simultaneously visual motion. Then, some codes were given to indicate the subject in the conversation transcript. In this case, the "Gp" code is for the group presenter, the "Gc" code is for the checker group, and the "Go" code is for the observer group. Then, we reconstructed the subject's sentences into well-organized and easy-to-understand sentences. We performed this stage since transcripts contain verbal speech from subjects whose sentence structure is not standard and sometimes difficult to understand. Therefore, the verbal language in the transcript was different from the written language that will be presented in this study. We have conducted member checks through stages namely; (1) selecting the presenter group, the checker group, and the observer group involved in a discussion on a particular topic of linear algebra, (2) giving the interpretation of audio transcript to the three groups, (3) asking them to observe the video while examining the contents of the transcript, (4) confirm through question and answer directly, (5) record improvements if applicable. In addition to video data, we also qualitatively analyzed PMT test answers. We analyze the work of PMTs through stages; (1) classifying the work of PMTs based on the similarity of the answers, (2) counting the number of test respondents who have the same answers in each group, (3) selecting the work of PMTs that will be presented in the discussion. We selected the works of PMTs based on the number of test respondents who have the same answers, at least half of the total respondents of the test (Sartika, 2017), (4) associating the work of PMTs with the video data, and (5) interpreting the meaning and explain it narratively.

\section{Findings and Discussion}

In this section, we begin by giving quantitative results from the experiments in two different PMTs groups taught by $\mathrm{PbL}$ with role-playing and $\mathrm{PbL}$ only. Then, we interpret the learning process supported by some of the PMTs' work from both groups and parts of the recorded mathematical discussion to answer the second question.

Table 2. The result of the reliability test

\begin{tabular}{lcc}
\hline & Control group & Experimental group \\
\hline Mean & 57.84 & 73.33 \\
Minimum & 45.8 & 61.4 \\
Maximum & 68.8 & 82.6 \\
Sum & 1214.6 & 1539.9 \\
Score Odd Number & 132 & 268 \\
Score Even Number & 134 & 268 \\
$R$ & 0.38 & 0.42 \\
$t$ Critical one-tail & 2.04 & \\
$r$ Critical one-tail & 0.36 & \\
Count & 21 & \\
\hline
\end{tabular}


First, we present the results of the reliability test used a product-moment correlation. The results show that the tests used in both groups are reliable (Table 2). We also present the results of PMTs' problem-solving skills in the experimental and control groups are shown in Table 3.

Table 3. The post-test results

\begin{tabular}{lcc}
\hline & Experimental group & Control group \\
\hline Mean & 73.33 & 57.84 \\
Standard Error & 1.29 & 1.57 \\
Median & 72.5 & 57.4 \\
Mode & 72.5 & 65.8 \\
Standard Deviation & 5.90 & 7.18 \\
Sample Variance & 34.86 & 51.55 \\
Kurtosis & -0.63 & -0.96 \\
Skewness & -0.25 & -0.26 \\
Range & 21.2 & 23 \\
Minimum & 61.4 & 45.8 \\
Maximum & 82.6 & 68.8 \\
Sum & 1539.9 & 1214.6 \\
Count & 21 & 21 \\
Z-Skewness & -0.46 & -0.49 \\
Z-Kurtosis & 0.59 & -0.90 \\
\hline
\end{tabular}

Table 3 shows that the values of Z-Skewness and Z-Kurtosis are between -1.96 and +1.96 which indicate that the experimental groups and the control groups are normally distributed. Meanwhile, the homogeneity test through the F-test (Table 4) shows that the critical value for F distribution is larger than the table value for the F distribution $(\alpha=0.05)$, which means the data variant is not homogeneous.

Table 4. The F-test results

\begin{tabular}{lcc}
\hline & Experimental group & Control group \\
\hline Mean & 73.33 & 57.84 \\
Variance & 34.86 & 51.55 \\
Observations & 21 & 21 \\
$d f$ & 20 & 20 \\
$F$ & 0.68 & \\
$P(F<=f)$ one-tail & 0.19 & \\
$F$ Critical one-tail & 0.47 & \\
\hline
\end{tabular}

Since the data variants are not homogeneously shown in Table 4 then hypothesis testing was conducted by using a t-test: two-sample assuming unequal variances. The results are shown in Table 5. It shows that the critical value of $t$ is larger than the table value of $t$ distribution $(\alpha=$ 0.05). It means that the result of PMTs' problem-solving taught by $\mathrm{PbL}$ with role-playing is greater than those who have been taught with $\mathrm{PbL}$ only. Thus, $\mathrm{PbL}$ with role-by playing is more effective to improve the PMTs' problem-solving skills on linear algebra.

The improvement of PMTS' problem-solving skills in the experimental group is supported by a good understanding of the concept of linear algebra. This understanding is developed not only through the practice of solving the given mathematical problems, but also built through the process of playing roles. PMTs from the experimental group have better problem-solving skills 
compared to PMTs from the control group. Now, we present one of the problems used to examine PMTs' problem-solving skills. In this case, they were asked to determine the solution of a linear system using the Gauss-Jordan elimination method as follows.



Table 5. The t-test results

\begin{tabular}{lcc}
\hline & Experimental group & Control group \\
\hline Mean & 73.33 & 53.410 \\
Variance & 34.86 & 105.624 \\
Observations & 21 & 21 \\
Hypothesized Mean Difference & 0 & \\
$d f$ & 39 & \\
$t$ Stat & 7.64 & \\
$P(T<t)$ one-tail & 0.00 & \\
$t$ Critical one-tail & 1.68 & \\
$P(T<=t)$ two-tail & 0 & \\
$t$ Critical two-tail & 2.02 & \\
\end{tabular}

PMTs from the control group were asked to determine the solution of a linear system by Gauss-Jordan Elimination, but in fact, they completed using common elimination (Figure 1). PMTs from the control group failed to distinguish the terms between common elimination and Gauss-Jordan Elimination. The common elimination method can indeed be used to determine the solution of a linear system, but in this case, they were strongly asked to determine the solution of a linear system only with the Gauss-Jordan Elimination method. When solving problems, PMTs will go through a process of interpretation of mathematical language and the process of calculation. This process requires PMTs to be able to interpret language into numbers and equations. PMTs have difficulty understanding the language, sentences, or words they read in the problem, so the problem-solving strategies they use do not fit the context of the problem. PMTs in higher education sometimes cannot avoid such mistakes when solving problems (AduGyamfi, Bossé, \& Chandler, 2015). Many teaching practices show the fact that mistakes are caused because they do not get the necessary feedback about the work they have completed during the math class (Prank et al., 2007). Although PMTs take courses on linear algebra throughout their undergraduate education, the results obtained from this study show that the prospective teachers' mathematical content knowledge lacks adequate understanding (Şahin, Gökkurt, \& Soylu, 2016).

Different results are shown by PMTs in the experimental group. They were quite capable to solve the problem. PMTs could employ the Gauss-Jordan elimination methods according to the question in the test. PMTs already knew that Gauss-Jordan elimination methods use row elementary operation, so they employed matrices and not with common elimination (Figure 2). 


\section{Translation:}

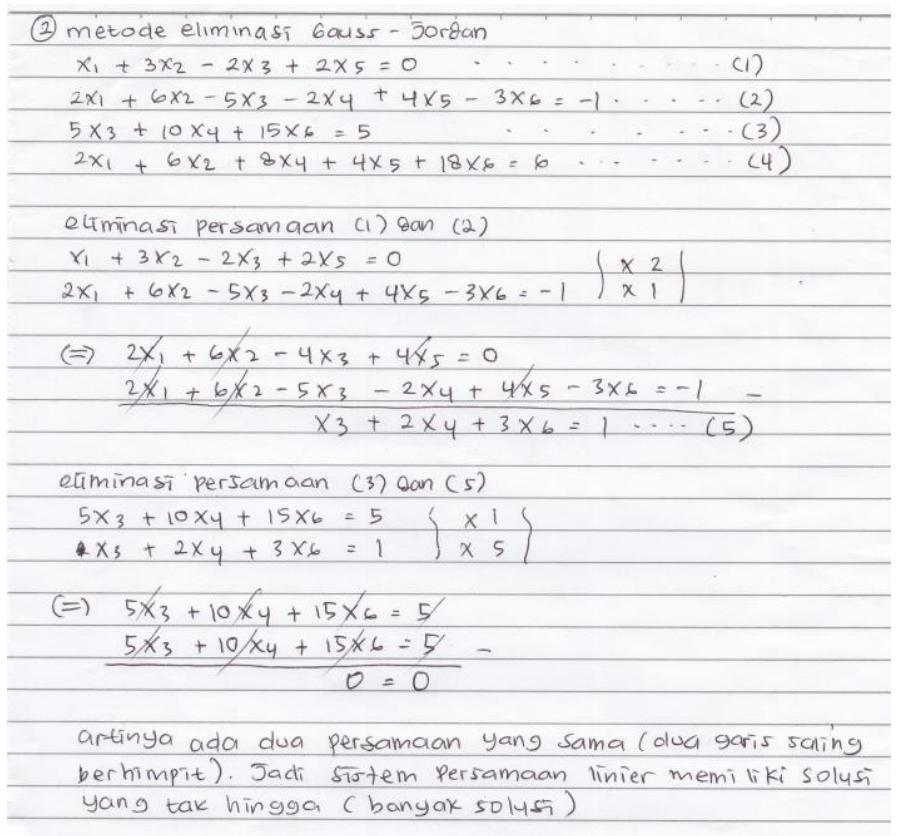

Eliminasi Gauss-Jordan = GaussJordan Elimination

Eliminasi persamaan (1) dan (2) = eliminate the first equation with the second equation

Eliminasi persamaan (3) dan (5) = eliminate the third equation with the fifth equation

That means there are two similar equations (two lines coincide). so the system of linear equations has an infinite solution

Figure 1. One of PMTs' sample works from the control group

PMTs from the experimental group can carry out the Gauss-Jordan elimination method correctly so that they can make conclusions where the linear system has infinite solutions. Besides that, it turns out they made no complete conclusion because they did not write the general solution of the linear system. The solution should be written as follows:

"The row of zeros leads to equation $0 x_{1}+0 x_{2}+0 x_{3}+0 x_{4}+0 x_{5}+0 x_{6}=0$, which places no restrictions on the solutions. Thus, we can omit this equation and write the corresponding system as

$$
\begin{gathered}
x_{1}+3 x_{2}-2 x_{3}+2 x_{5}=0 \\
x_{3}+2 x_{4}+3 x_{6}=1 \\
x_{6}=\frac{1}{3}
\end{gathered}
$$

Here $x_{1}, x_{3}, x_{6}$ are the leading variables, and $x_{2}, x_{4}, x_{5}$ are the independent variables. Solving for the leading variables in terms of the independent variables gives

$$
\begin{gathered}
x_{1}=-3 x_{2}+2 x_{3}-2 x_{5} \\
x_{3}=1-2 x_{4}-3 x_{6} \\
x_{6}=\frac{1}{3}
\end{gathered}
$$

Sequentially, since the free variables can be assigned an arbitrary value, that is $r$ for $x_{2}$, sfor $x_{4}$, and $t$ for $x_{5}$, then the linear system have infinitely many solutions. Therefore, the general solution is given by the formulas

$$
\begin{gathered}
x_{1}=-3 r-4 s-2 t \\
x_{3}=-2 s \\
x_{6}=\frac{1}{3}
\end{gathered}
$$




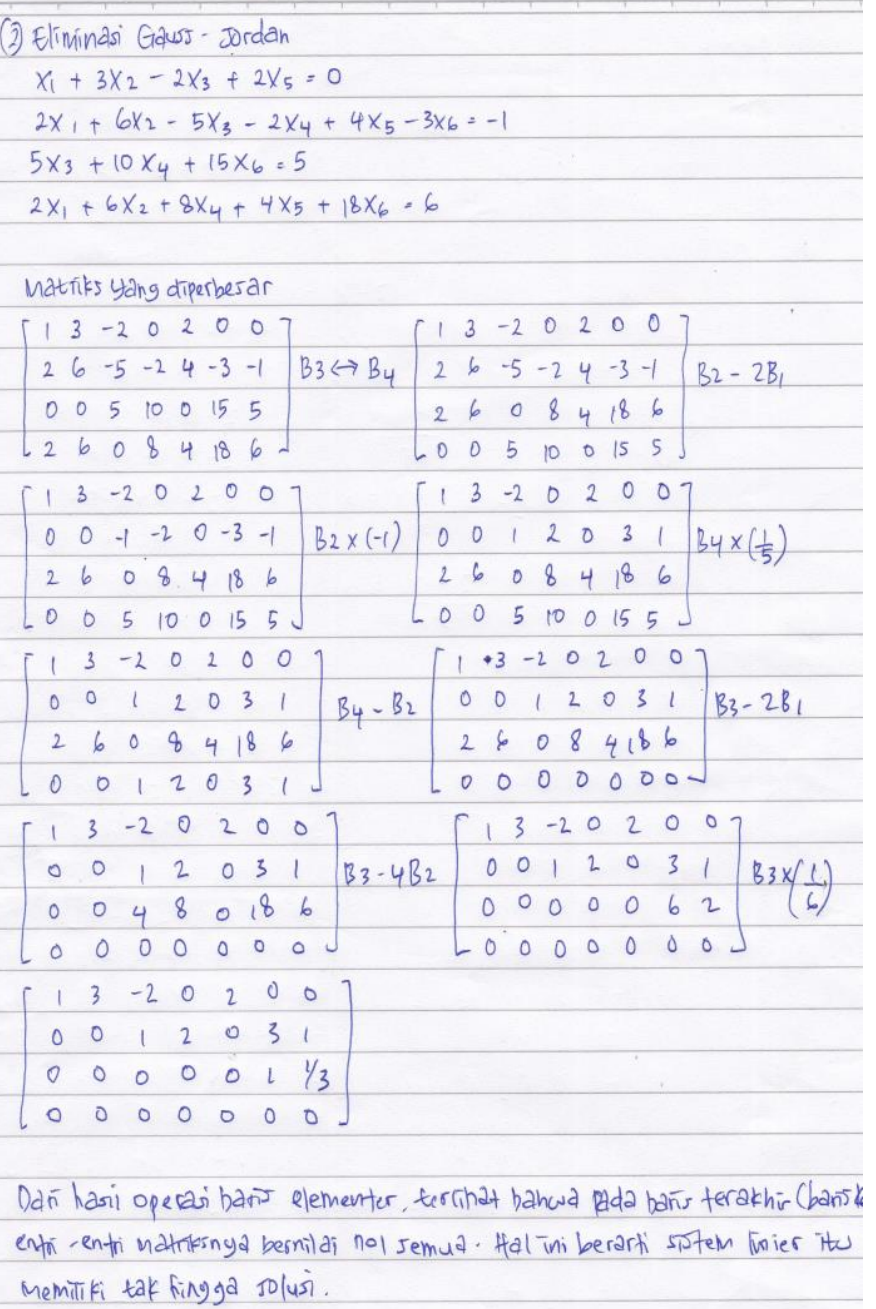

\section{Translation:}

Eliminasi Gauss-Jordan = Gauss-Jordan Elimination

Matriks yang diperbesar $=$ Augmented Matrix

$B_{3} \leftrightarrow B_{4}=$ interchange all entries in the third row with all entries in the fourth row $B_{2}-2 B_{1}=B_{2}+\left(-2 B_{1}\right)=$ adding all entries in the second row by the negative multiples of two of all entries in the first row

$B_{2} \times(-1)=$ multiplying all entries in the second row by -1

$B_{4} \times \frac{1}{5}=$ multiplying all entries in the fourth row by $\frac{1}{5}$

$B_{4}-B_{2}=B_{4}+\left(-B_{2}\right)=$ adding all entries in the fourth row by negative multiples of all entries in the second row

$B_{3}-2 B_{1}=B_{3}+\left(-2 B_{1}\right)=$ adding all entries in the third row by the negative multiples of two of all entries in the first row

$B_{3}-4 B_{2}=B_{3}+\left(-4 B_{2}\right)=$ adding all entries in the third row by the negative multiples of four of all entries in the second row

$B_{3} \times \frac{1}{6}=$ multiplying all entries in the fourth row by $\frac{1}{6}$

Based on the results of elementary row operations, it appears that the last matrix has a row in which all entries are zero (in the fourth row). This can be interpreted that the linear system has an infinite solution.

Figure 2. One of PMTs' sample works from the experimental group

Here we present footage from PMTs in a video showed how they learn to do elementary row operation.

\section{Transcript 1}

$1 \quad G_{p}:$ : "Today we will discuss how to do elementary row operations. Since the rows (horizontal lines) of an augmented matrix correspond to the equations in the associated system, these three operations correspond to the following operations on the rows of the augmented matrix; (1) multiply a row through by a nonzero constant, (2) interchange two rows, and (3) add a multiple of one row to another row"

$2 G_{c}$ : "What is the purpose of using these three operations?"

$3 \quad G_{p}$ : "We use these operations to obtain a matrix that is in the reduced row-echelon form"

$4 G_{c}$ : "What is the meaning of a matrix in reduced row-echelon form?" 
$5 \quad G_{p}:$ : "A matrix in reduced row-echelon form has these following properties; (1) if a row does not consist entirely of zeros, then the first nonzero number in the row is a 1. We call this a leading 1, (2) if any rows consist entirely of zeros, then they are grouped at the bottom of the matrix, (3) in any two successive rows that do not consist entirely of zeros, the leading 1 in the lower row occurs farther to the right than the leading 1 in the higher row, and (4) each column that contains a leading 1 has zeros everywhere else in that column"

$6 G_{o}$ : "I think we need an example to make your explanation is clear for all of us"

$7 \quad G_{p}:$ "Ok, let we have a matrix $\left[\begin{array}{llll}1 & 0 & 0 & 1 \\ 0 & 1 & 0 & 2 \\ 0 & 0 & 1 & 3 \\ 0 & 0 & 0 & 0\end{array}\right]$ that already in reduced row-echelon form. Assume this matrix associated with a linear system. Then, we can say that the value of $x_{1}=1, x_{2}=2$, and $x_{3}=3$. So the linear system has a unique solution.

$8 G_{o}:$ "If we have a matrix $\left[\begin{array}{llll}1 & 0 & 0 & 1 \\ 0 & 1 & 0 & 2 \\ 0 & 0 & 1 & 3 \\ 0 & 0 & 0 & 4\end{array}\right]$ then how to determine the solution of a linear system that related with?

$9 G_{p}$ : "Based on the fourth row, since we have the value of the real constants are $a_{1}=$ $a_{2}=a_{3}=0 \& b=4$, then it means that the linear system has no solution. We know that $x_{1}+x_{2}+x_{3}=4 \leftrightarrow 0+0+0+0=4$ is contradictory"

$10 G_{c}$ : "How about the linear system that has an infinite solution?"

$11 \quad G_{p}:$ "Let we have a matrix $\left[\begin{array}{lllll}1 & 0 & 0 & 1 & 1 \\ 0 & 1 & 0 & 0 & 2 \\ 0 & 0 & 1 & 0 & 3\end{array}\right]$, then we can write that $x_{1}+x_{4}=$ $1, x_{2}=2, x_{3}=3$. Since $x_{4}$ can be assigned an arbitrary value, $t$, there are infinitely many solutions. The general solution is given by the formulas $x_{1}=1-$ $t, x_{2}=2, x_{3}=3, x_{4}=t$

While engaging in mathematics, role-playing allows PMTs to talk mathematics to the whole class, talk not only to one another but also aloud to themselves (Kotsopoulos, 2010). PMTs also have the opportunity to confirm their knowledge obtained and develop through analyzing or confronting mathematics questions. Playing roles through class discussion encourages PMTs and the lecturer to work as a community to share, compare, justify, and interrogate various strategies to solve problems (Bray, 2011). It is understandable since mathematics concepts and tasks which are frequently experienced through collaborative instruction are mastered more readily than those which are less frequently experienced. Classroom experiences may diminish the perceived misunderstanding of the mathematical term (Bossé, Adu-Gyamfi, \& Cheetham, 2011). Now, we provide a transcript illustrates role-playing performed by PMTs from the experimental group. They discussed the theorem related to elementary row operations (Figure 3). This theorem is useful to help PMTs have a better understanding of the Gauss-Jordan Elimination as one of the methods to find a solution to a linear system.

\section{Transcript 2}

$1 \quad G_{p}:$ We will give an example of a $3 \times 3$ matrix to illustrate the theorem 2.2.3(b). 
Let $A=\left[\begin{array}{lll}a_{11} & a_{12} & a_{13} \\ a_{21} & a_{22} & a_{23} \\ a_{31} & a_{32} & a_{33}\end{array}\right]$ and if the first row and the second row of $A$ are interchanged, then $B=\left[\begin{array}{lll}a_{21} & a_{22} & a_{23} \\ a_{11} & a_{12} & a_{13} \\ a_{31} & a_{32} & a_{33}\end{array}\right]$. Since $\operatorname{det}(A)=\left(a_{11} a_{22} a_{33}+\right.$ $\left.a_{12} a_{23} a_{31}+a_{13} a_{21} a_{32}\right)-\left(a_{11} a_{23} a_{32}+a_{12} a_{21} a_{33}+a_{13} a_{22} a_{31}\right)$, and $\operatorname{det}(B)=\left(a_{11} a_{23} a_{32}+a_{12} a_{21} a_{33}+a_{13} a_{22} a_{31}\right)-\left(a_{11} a_{22} a_{33}+a_{12} a_{23} a_{31}+\right.$ $\left.a_{13} a_{21} a_{32}\right)=-\operatorname{det}(A)$, so it is can be said that $\operatorname{det}(B)=-\operatorname{det}(A)$

$2 G_{c}$ : What properties and methods are needed to prove the theorem?

$3 G_{p}$ : We need to use the commutative of multiplication and the commutative of addition to performing the Sarrus method.

$4 G_{c}$ : Why does the interchange of two rows of matrix A can affect the determinant value?

$5 G_{p} \quad: \quad$ Since two rows of A are interchanged then the product of their entries will change too.

$6 G_{o}:$ We observe that the presenter group explanation has not been connected with elementary row operations, while the theorem is related to.

$7 G_{p}$ : Elementary row operations are certainly used in this mathematical process. It is shown when two rows of matrix A are interchanged.

$8 G_{c}$ : Can you give us an insight into what knowledge we can get about this theorem?

$9 G_{p}$ : The theorem teaches us that an elementary row operation on a matrix A can produce a new matrix $B$ that has a different determinant value than matrix $A$.

$10 G_{c}:$ Now it seems that this case is clear for us, but we think of another case that related to it. What will happen if the rows in matrix B interchange?

$11 G_{p}:$ We think that if we use the same elementary row operation, exchanging two rows on a matrix $B$, it will remain that the $\operatorname{det}(B)=-\operatorname{det}(A)$.

$12 G_{c}:$ Can you show it?

Let $A=\left[\begin{array}{lll}a_{11} & a_{12} & a_{13} \\ a_{21} & a_{22} & a_{23} \\ a_{31} & a_{32} & a_{33}\end{array}\right]$ and if the first-row interchange with the second row, thus $B=\left[\begin{array}{lll}a_{21} & a_{22} & a_{23} \\ a_{11} & a_{12} & a_{13} \\ a_{31} & a_{32} & a_{33}\end{array}\right]$, and continued with the second row exchanged with the third row such that $B^{\prime}=\left[\begin{array}{lll}a_{21} & a_{22} & a_{23} \\ a_{31} & a_{32} & a_{33} \\ a_{11} & a_{12} & a_{13}\end{array}\right]$ is obtained, thus $\operatorname{det}\left(B^{\prime}\right)=$ $\left(a_{11} a_{22} a_{33}+a_{12} a_{23} a_{31}+a_{13} a_{21} a_{32}\right)-\left(a_{11} a_{23} a_{32}+a_{12} a_{21} a_{33}+\right.$ $\left.a_{13} a_{22} a_{31}\right)=\operatorname{det}(A)$

$14 G_{c}:$ How is the result? Did that answer your hypothesis?

$15 G_{p}:$ It turns out that our hypothesis was not proven because $\operatorname{det}\left(B^{\prime}\right)=\operatorname{det}(A)$ where $B$ ' is a matrix produced from matrix $B$ by exchanging two different rows.

$16 G_{o}$ : Based on the presenter group explanation, it seems that how much we do the interchange of two different rows in a matrix will change its determinant value. Based on the findings of the checker group, we think the determinant of new matrices depends on the odd or even number of row interchange.

$17 G_{c}$ : How do you show that the hypothesis is accepted?

$18 G_{o}$ : Based on previous results it is known that:

" if the first row of matrix $A$ interchange for the second row it will produce a matrix $B$, then $\operatorname{det}\left(B^{\prime}\right)=-\operatorname{det}(A)$ ", and we continue as

"if the second row of matrix $B$ interchange for the third row it will produce a matrix $B^{\prime}$, then $\operatorname{det}\left(B^{\prime}\right)=\operatorname{det}(A)$ " 
Now we continued one more time by interchange the first row of matrix $B$ ' for the third row, thus obtained $B^{\prime \prime}=\left[\begin{array}{lll}a_{11} & a_{12} & a_{13} \\ a_{31} & a_{32} & a_{33} \\ a_{21} & a_{22} & a_{23}\end{array}\right]$. The result isdet $\left(B^{\prime \prime}\right)=$ $\left(a_{11} a_{23} a_{32}+a_{12} a_{21} a_{33}+a_{13} a_{22} a_{31}\right)-\left(a_{11} a_{22} a_{33}+a_{12} a_{23} a_{31}+\right.$ $\left.a_{13} a_{21} a_{32}\right)=-\operatorname{det}(A)$.

After going through some investigation, we know that the theorem can be expanded to another situation related to it.

"Let $A$ be $n \times n$ matrix. If two rows interchange on matrix $A$ to produce matrix $B$ and on and on in odd numbers then $\operatorname{det}(B)=-\operatorname{det}(A)$ and if in even number then $\operatorname{det}(B)=\operatorname{det}(A)$ ". But in this case, we have to remember that the rows exchanges carried out must produce matrices that are different from each other.

THEOREM 2.2.3

Let $A$ be an $n \times n$ matrix.

(a) If $B$ is the matrix that results when a single row or single column of $A$ is multiplied by a scalar $k$, then $\operatorname{det}(B)=k \operatorname{det}(A)$.

(b) If $B$ is the matrix that results when two rows or two columns of $A$ are interchanged, then $\operatorname{det}(B)=-\operatorname{det}(A)$.

(c) If $B$ is the matrix that results when a multiple of one row of $A$ is added to another row or when a multiple of one column is added to another column, then $\operatorname{det}(B)=\operatorname{det}(A)$.

Figure 3. Theorem 2.2.3, taken from Anton and Rorres (2005)

Transcript 2 revealed that the presenter group performed its role to explain a mathematical topic (Line 1, 3, 5, 7, 9, 11, and 13), while the checker group did its role to confirm so that the topic explanation from the presenter group can be logically accepted as true (Line 2, 4, 8, 10, 12,14 , and 17). Meanwhile, the observer group performed its role to provide reflections that can complement all the information that has been obtained (Line 6, 16, and 18). The way of PMTs work in understanding the topic and solving mathematical problems through role-playing has a positive impact on the growth of learning motivation and cognitive strategies that underlie the improvement of PMTs' problem-solving skills. The discussion went fairly smoothly, there was a multi-directional interaction between the presenter groups, the checker group, and the observer group. All the PMTs were still eager to keep exploring the topic until it was complete. This study showed that when the PMTs play their role to have meaningful mathematics talks, it can help sustain their motivation and engagement during their effort to explain a theorem or to find the solution of the linear system. Motivation and learning strategies are important factors to improve prospective teacher's abilities (Murayama et al., 2013). Collaboration in small groups can activate student knowledge about prerequisite topics that are important to use to explain a problem and build understanding. This process will encourage students to continue to search for relevant information until they find new information related to the problem being solved (Schmidt, Rotgans, \& Yew, 2011).

This study indicates that PMTs who learn linear algebra through problem-based learning with role-playing enables them to improve their understanding of the characteristics of linear systems, the types of linear system solutions, and various methods to determine linear system 
solutions. This achievement is supported by the success of PMTs in carrying out their roles according to agreed rules. Role-playing improves the quality of interaction between group members. However, it has to remember that during the discussion, the lecturer has to keep observing, analyzing, and directing the PMTs' conversation on mathematics content. A productive learning environment must be able to provide flexibility where PMTs can explore, collaborate, and use disciplined and critical thinking in solving problems (Mishra, Fahnoe, \& Henriksen, 2013). Collaboration is a mutual engagement of prospective teachers in a coordinated effort to solve a problem together (Lai, 2011). Hence, PbL with role-playing involves participants working together on the same task, rather than in parallel on separate portions of the task. The PMTs act through their respective roles to discuss and solve a similar problem. In this way, PMTs will help each other to find new knowledge by connecting their prior-knowledge to current problems, doing mathematics operations to answers the hypotheses, and making logical conclusions based on findings. One of the greatest and inevitable challenges faced by educators is to determine the most effective teaching approach for their prospective teachers (Tsay \& Brady, 2010). Therefore, a mathematics educator must have a good understanding of the level of PMTs' thinking process. As PMTs are on their way of becoming a teacher, a mathematics educator must determine a learning approach that reflects adult learning. Prospective teachers as adult learners must be treated with a learning approach that can make them independent and responsible. Prospective teachers think that deep experience is an important component in learning that achieve through cooperation and motivation (Kenner \& Weinerman, 2011).

In our study, PMTs seem to solve simple mathematics problems, in line with the term of closed-problems or structured-problem or routine problems (Nissa, 2015). PMTs attempt to find the linear-system solutions with elementary row operation, which is the basic procedure in linear algebra. In some perspectives, such mathematical problems are not challenging to solve. But somehow, in the $\mathrm{PbL}$ concept, a mathematical problem can be said to be a problem if such a problem has never been encountered. According to the structure of the school and higher education mathematics curriculum, it is obvious that PMTs have never studied about the elementary row operations, even though prior knowledge such as linear equations and matrices has been learned while in school. Related with $\mathrm{PbL}$, some studies concern about how to develop or implement mathematics problems to achieve problem-solving skills, i.e., open-ended problems (Bragg \& Nicol, 2008; Kurniawan, Putri, \& Hartono, 2018), and mathematics PISAlike problems (Jannah, Putri, \& Zulkardi, 2019; Oktiningrum, Zulkardi, Hartono, 2016; Putri \& Zulkardi, 2020). Therefore, our study contributes to exploring the process of how to build problem-solving skills. Not only depends on how sophisticated mathematical problems PMTs have to solve, but the process of how they acquire problem-solving skills is equally important. Learning mathematics is complicated, especially for PMTs in higher education. The mathematics topics that must be addressed by PMTs in higher education have different levels of difficulty compared to the mathematics topics they learned while at school. Providing sophisticated mathematical problems without regard to how their processes build understanding of mathematics will make it difficult for them to learn mathematics.

For long-term research-teaching design, it is hard to maintain consistency and motivation of PMTs to play a role in the classroom, since various destructive can occur due to their own way to learn mathematics, getting impasse in solving problems, or failure in connecting and communicating ideas. Thus, related to the context of adult learning, the success of the learning process depends on the persistence and involvement of PMTs. Moreover, such global teaching designs should be evaluated through various approaches and tools, since there are a number of 
factors that can influence their success. However, internal evaluations have been carried out and have shown some positive effects. Mathematics education research cannot provide concise solutions to overcome some difficulties in learning and teaching about linear algebra. Various studies have been carried out such as diagnosing student difficulties, epistemological analysis, and experimental teaching, which offer local remediation (Dorier, 2003). However, similar research is advised to continue to address new problems and difficulties in learning and teaching linear algebra. Cognitive processes in mathematics are too complicated to be seen in a simple and idealistic way. That is deeper knowledge about the nature of concepts. Therefore, rich-task and flexible teaching is highly recommended, because a class is a dynamic environment with a variety of factors that influence it.

\section{Conclusion}

The results of this study indicate that PMTs who learn linear algebra through PbL with roleplaying show a significant improvement in problem-solving skills rather than PMTs who learn only through $\mathrm{PbL}$. The collaboration between $\mathrm{PbL}$ and role-playing generates a proficient strategy to assist PMTs to learn mathematics critically and collaboratively. PbL facilitates PMTs to learn mathematics through problems related to concepts and procedures, while role-playing support PMTs to think critically through collaborative discussion. Also, $\mathrm{PbL}$ with role-playing leads PMTs to strengthen understanding and problem-solving skills. Based on these findings, we consider teaching mathematics in higher education could refer to $\mathrm{PbL}$ with role-playing as alternative learning approaches with providing appropriate direction, questions, and feedback to keep the PMTs perform discussion on the right trajectory. Furthermore, according to the limitation of present study, we recommend conducting similar studies on the subjects who are homogeneous on variance to notice how role-playing assist PMTs in problem-solving, especially through discussion activities or investigate $\mathrm{PbL}$ with different role-playing and activities.

\section{References}

Adu-Gyamfi, K., Bossé, M. J., \& Chandler, K. (2015). Situating student errors: Linguistic-to-algebra translation errors. International Journal for Mathematics Teaching \& Learning, 1, 1-5. Retrieved from http://www.cimt.org.uk/journal/bosse6.pdf

Alayont, F., Babenko, Y., Jackson, C., \& Szaniszlo, Z. (2014). Challenges in promoting undergraduate research in the mathematical sciences. Involve: A Journal of Mathematics, 7(3), 265-271. Doi:10.2140/involve.2014.7.265

Anton, H., \& Rorres, C. (2005). Elementary linear algebra: Applications version (9th edition).New Jersey: John Wiley \& Sons, Inc.

Ar, A. A., \&Katranc1, Y. (2014). The opinions of primary mathematics student-teachers on problembased learning method. Procedia - Social and Behavioral Sciences, 116, 1826-1831. Doi: 10.1016/j.sbspro.2014.01.478

Argaw, A. S., Haile, B. B., Ayalew, B. T., \& Kuma, S. G. (2017). The effect of problem based learning $(\mathrm{PbL})$ instruction on students' motivation and problem solving skills of physics. Eurasia Journal of Mathematics, Science and Technology Education, 13(3), 857-871. Doi: 10.12973/eurasia.2017.00647a

Armstrong, E. K. (2003). Applications of role-playing in tourism management teaching: An evaluation of a learning method. The Journal of Hospitality Leisure Sport and Tourism, 2(1), 5-16. Doi: $10.3794 /$ johlste. 21.24

Bender, T. (2005). Role playing in online education: A teaching tool to enhance student engagement and 
sustained learning. Innovate: Journal of Online Education, 1(4),1-6.

Bhattacharjee, S., \& Ghosh, S. (2013). Usefulness of role-playing teaching in construction education: A systematic review. Paper presented at 49th ASC Annual International Conference, San Luis Obispo, CA.

Biggs, J., \& Tang, C. (2011). Contexts for effective teaching and learning. In C. Tang \& J. Biggs (Eds.). Teaching for quality learning at university (pp. 58-80). New York: Mc Graw Hill.

Bossé, M. J., Adu-Gyamfi, K., \& Cheetham, M. R. (2011). Assessing the difficulty of mathematical translations: Synthesizing the literature and novel findings. International Electronic Journal of Mathematics Education, 6(3), 113-133.

Bragg, L. A., \& Nicol, C. (2008). Designing open-ended problems to challenge preservice teachers' views on mathematics and pedagogy. Paper Presented at Conference of the International Group for the Psychology of Mathematics Education, Mexico.

Brandt, J., Lunt, J., \& Meilstrup, G. R. (2016). Mathematicians' and math educators' views on 'doing mathematics." PRIMUS, 26(8), 753-769. Doi: 10.1080/10511970.2016.1166408

Bray, W. S. (2011). A collective case study of the influence of teachers' beliefs and knowledge on errorhandling practices during class discussion of mathematics. Journal for Research in Mathematics Education, 42(1), 2-38. Doi:10.5951/jresematheduc.42.1.0002

Chan, Z. C. Y. (2012). Role-playing in the problem-based learning class. Nurse Education in Practice, 12(1), 21-27. Doi: 10.1016/j.nepr.2011.04.008

Davidson, N., Major, C. H., \& Michaelsen, L. K. (2014). Small-group learning in higher educationcooperative, collaborative, problem-based, and team-based learning: An introduction by the guest editors. Journal on Excellence in College Teaching, 25(3\&4), 1-6.

De Simone, C. (2008). Problem-based learning: A framework for prospective teachers' pedagogical problem solving. Teacher Development, 12(3), 179-191. Doi: 10.1080/13664530802259206

Dochy, F., Segers, M., Van den Bossche, P., \& Gijbels, D. (2003). Effects of problem-based learning: A meta-analysis. Learning and Instruction, 13(5), 533-568. Doi: 10.1016/S0959-4752(02)00025-7

Dolmans, D. H. J. M., De Grave, W., Wolfhagen, I. H. A. P., \& Van Der Vleuten, C. P. M. (2005). Problem-based learning: Future challenges for educational practice and research. Medical Education, 39(7), 732-741. Doi: 10.1111/j.1365-2929.2005.02205.x

Dorier, J.-L. (2003). Teaching linear algebra at university. Paper Presented at International Congress of Mathematicians, China. Retrieved from https://arxiv.org/pdf/math/0305018.pdf

Fata, I. A., Kasim, U., \& Juniyana, D. (2016). Setting sight on role playing: To accommodate or to repudiate? Lingua Cultura, 10(2), 83-88. Doi: 10.21512/lc.v10i2.941

Goodyear, P. (2005). Educational design and networked learning: Patterns, pattern languages and design practice. Australasian Journal of Educational Technology, 21(1), 82-101. Doi: 10.14742/ajet.1344

Gregory, S., \& Masters, Y. (2012). Real thinking with virtual hats: A role-playing activity for pre-service teachers in second life. Australasian Journal of Educational Technology, 28(3), 420-440. Doi: 10.14742/ajet.843

Hmelo-Silver, C. E. (2004). Problem-based learning: What and how do students learn? Educational Psychology Review, 16(3), 235-266. Doi:10.1023/B:EDPR.0000034022.16470.f3

Howes, E. V., \& Cruz, B. C. (2009). Role-playing in science education: An effective strategy for developing multiple perspectives. Journal of Elementary Science Education, 21(3), 33-46. Doi: $10.1007 / \mathrm{bf} 03174721$

Hung, W., Jonassen, D. H., \& Liu, R. (2008). Problem-based learning. Handbook of Research on Educational Communications and Technology, 3(1), 485-506.

Jackson, P. T., \& Walters, J. P. (2000). Role-playing in analytical chemistry: The alumni speak. Journal of Chemical Education, 77(8), 1019-1024. Doi: 10.1021/ed077p1019

Jannah, R. D., Putri, R. I. I., \& Zulkardi. (2019). Soft tennis and volleyball contexts in asian games for pisa-like mathematics problems. Journal on Mathematics Education, 10(1), 157-169. Doi: 10.22342/jme.10.1.5248.157-170

Jupri, A., \& Drijvers, P. (2016). Student difficulties in mathematizing word problems in Algebra. Eurasia Journal of Mathematics, Science and Technology Education, 12(9), 2481-2502. Doi: 10.12973/eurasia.2016.1299a

Kenner, C., \& Weinerman, J. (2011). Adult learning theory: Applications to non-traditional college students. Journal of College Reading and Learning, 41(2), 87-96. Doi: 10.1080/10790195.2011.10850344 
Kilgour, P. W., Reynaud, D., Northcote, M. T., \& Shields, M. (2015). Role-playing as a tool to facilitate learning, self reflection and social awareness in teacher education. International Journal of Innovative Interdisciplinary Research, 2(4), 8-20.

Kotsopoulos, D. (2010). An analysis of talking aloud during peer collaborations in mathematics. International Journal of Science and Mathematics Education, 8(6), 1049-1070. Doi: 10.1007/s10763010-9221-8

Kurniawan, H., Putri, R. I. I., \& Hartono, Y. (2018). Developing open-ended questions for surface area and volume of beam. Journal on Mathematics Education, 9(1), 157-168. Doi: 10.22342/jme.9.1.4640.157-168

Lai, E. R. (2011). Collaboration: A literature review. Retrieved from https://images.pearsonassessments.com/images/tmrs/Collaboration-Review.pdf

Miliyawati, B., \& Herman, T. (2019). Effect of problem based learning with didactical engineering on student mathematical disposition. Journal of Physics: Conference Series, 1315(1), 1-6. Doi: 10.1088/1742-6596/1315/1/012021

Mishra, P., Fahnoe, C., \& Henriksen, D. (2013). Creativity, self-directed learning and the architecture of technology rich environments. TechTrends, 57(1), 10-13. Doi: 10.1007/s11528-012-0623-z

Murayama, K., Pekrun, R., Lichtenfeld, S., \& vom Hofe, R. (2013). Predicting long-term growth in students' mathematics achievement: The unique contributions of motivation and cognitive strategies. Child Development, 84(4), 1475-1490. Doi: 10.1111/cdev.12036

Murray-Harvey, R., Curtis, D. D., Cattley, G., \& Slee, P. T. (2005). Enhancing teacher education students' generic skills through problem-based learning. Teaching Education, 16(3), 257-273. Doi: 10.1080/10476210500205025

Nissa, I. C. (2015). Pemecahan masalah matematika- Teori dan contoh praktek [Mathematics problem solving-Theory and practices]. Lombok: Duta Pustaka Ilmu.

Nurtanto, M., \& Sofyan, H. (2015). Implementasi problem-based learning untuk meningkatkan hasil belajar kognitif, psikomotor, dan afektif siswa di SMK [The implementation of problem-based learning to increase students' achievement in cognitive, psychomotor, and affective in vocational schools]. Jurnal Pendidikan Vokasi, 5(3), 352-364. Doi: 10.21831/jpv.v5i3.6489

Oktiningrum, W., Zulkardi., \& Hartono, Y. (2016). Developing PISA-like mathematics task with Indonesia natural and cultural heritage as context to assess students' mathematical literacy. Journal on Mathematics Education, 7(1), 1-8. Doi: 10.22342/jme.7.1.2812.1-8

Polly, D., Mcgee, J. R., Wang, C., Lambert, R. G., Pugalee, D. K., \& Johnson, S. (2013). The association between teachers' beliefs, enacted practices, and student learning in mathematics. The Mathematics Educator, 22(2), 11-30.

Prank, R., Issakova, M., Lepp, D., Tonisson, E., \& Vaiksaar, V. (2007). Integrating rule-based and inputbased approaches for better error diagnosis in expression manipulation tasks. Symbolic Computation and Education, 13(2), 174-191. Doi: 10.1142/9789812776006_0010

Prastiti, T. D., Suparti, Pamekas, Y., \& Martono. (2014). Pengembangan model tutorial berbasis masalah dan bermain peran untuk peningkatan pemahaman penelitian tindakan kelas pada mahasiswa universitas terbuka [Developing tutorial model based on problem and role-playing to understand classroom action research for students in open university] (Laporan penelitian). Universitas Terbuka. Retrieved from repository.ut.ac.id/5716/1/2014_247.pdf

Putri, R. I. I., \& Zulkardi. (2020). Designing PISA-like mathematics task using Asian games context. Journal on Mathematics Education, 11(1), 135-144. Doi: 10.22342/jme.11.1.9786.135-144

Rahman, F., Khalil, J. k., Jumani, N. B., Ajmal, M., Malik, S., \& Sharif, M. (2011). Impact of discussion method on students performance. International Journal of Business and Social Science, 2(7), 84-94.

Şahin, Ö., Gökkurt, B., \& Soylu, Y. (2016). Examining prospective mathematics teachers' pedagogical content knowledge on fractions in terms of students' mistakes. International Journal of Mathematical Education in Science and Technology, 47(4), 531-551. Doi: 10.1080/0020739X.2015.1092178

Sartika, R. (2017). University students' perception on conflicts in learning conflict resolution course. Edutech, 16(1), 85-97. Doi:10.17509/e.v16i1.7111

Schmidt, H. G., Rotgans, J. I., \& Yew, E. H. J. (2011). The process of problem-based learning: What works and why. Medical Education, 45(8), 792-806. Doi: 10.1111/j.1365-2923.2011.04035.x

Syaifudin, A., \& Sulistyaningrum, S. (2015). Peningkatan kemampuan berpendapat mahasiswa melalui problem based learning $(\mathrm{PbL})$ sebagai pendukung pencapaian Kerangka Kualifikasi Nasional Indonesia (KKNI) pada mata kuliah pragmatik [Improving students' reasoning ability through 
problem-based learning to support the achievement of Indonesian national qualification framework on pragmatic course]. Jurnal Penelitian Pendidikan, 32(2), 97-106.

Tsay, M., \& Brady, M. (2010). A case study of cooperative learning and communication pedagogy: Does working in teams make a difference? Journal of the Scholarship of Teaching \& Learning, 10(2), 7889.

Viholainen, A., Asikainen, M., \& Hirvonen, P. E. (2014). Mathematics student teachers' epistemological beliefs about the nature of mathematics and the goals of mathematics teaching and learning in the beginning of their studies. Eurasia Journal of Mathematics, Science and Technology Education, 10(2), 159-171. Doi: 10.12973/eurasia.2014.1028a

Wertsch, J. V. (2002). Computer mediation, PBL, and dialogicality. Distance Education, 23(1), 105-108. Doi: $10.1080 / 01587910220124008$

Wulanzani, U. T., Lestari, U., \& Syamsyuri, I. (2016). Hasil validasi buku teks matakuliah bioteknologi berbasis bahan alam tanaman pacing (costus speciosus smith) sebagai antifertilitas [Validating costus speciosus smith-based biotechnology textbook as anti-fertility]. Jurnal Pendidikan: Teori, Penelitian, dan Pengembangan, 1(9), 1830-1835.

Zazkis, R., \& Sinclair, N. (2013). Role playing in mathematics education. In A.M. Lindmeier \& A. Heinze (Eds.). Proceedings of the 37th Conference of the International Group for the Psychology ofMathematics Education, Vol. 1. Kiel, Germany: PME. 